\title{
Dietary protein-to-carbohydrate ratios affect metabolism and growth of juvenile surubim cachara (Pseudoplatystoma reticulatum)
}

\author{
André Fernando Nascimento Gonçalves ${ }^{1}$ - Natalia $\mathrm{Ha}^{1}$ • \\ Jaqueline Dalbello Biller-Takahashi ${ }^{1}$. \\ Rodrigo Yukihiro Gimbo ${ }^{2}$. \\ Elisabeth Criscuolo Urbinati ${ }^{2}$. \\ Leonardo Susumu Takahashi ${ }^{1,2}$
}

Received: 13 December 2016 / Accepted: 5 November 2017 /Published online: 17 November 2017

(C) Springer International Publishing AG, part of Springer Nature 2017

\begin{abstract}
This study was conducted to evaluate the effects of dietary carbohydrates (CHO) and protein on growth performance, nutrient retention, blood metabolites, tissue energy reserves (hepatic glycogen and lipids, mesenteric fat index, and hepatosomatic index), and key metabolic enzyme activities (hexokinase, glucokinase, glucose-6-phosphate dehydrogenase, and aspartate aminotransferase) of surubim cachara (Pseudoplatystoma reticulatum). Six experimental diets containing one of two CHO levels (170 or $300 \mathrm{~g} \mathrm{~kg}^{-1}$ ) and three crude protein (CP) levels $\left(360,400\right.$, or $440 \mathrm{~g} \mathrm{~kg}^{-1}$ ) were fed to four replicate groups of $P$. reticulatum $(69.2 \pm 4.4 \mathrm{~g})$ for 60 days. The results showed that $300 \mathrm{~g} \mathrm{~kg}^{-1} \mathrm{CHO}$ resulted in a worse final weight (FW, $208.4 \pm 26.9 \mathrm{~g}$ ), weight gain (WG, $139.4 \pm 23.9 \mathrm{~g}$ ), specific growth rate (SGR, $1.8 \pm 0.2 \%$ day $^{-1}$ ), apparent feed conversion (AFC, $1.5 \pm 0.3$ ), and protein efficiency ratio (PER, $163.7 \pm 23.4 \%$ ) than fish fed $170 \mathrm{~g} \mathrm{~kg}^{-1} \mathrm{CHO}(\mathrm{FW}, 241.4 \pm 37.3 \mathrm{~g}$; WG, $171.9 \pm 36.6 \mathrm{~g}$; SGR, $2.1 \pm 0.2 \%$ day $^{-1}$; AFC, $1.2 \pm 0.2$; PER, $\left.203.7 \pm 36.9 \%\right)$. Fish fed $170 \mathrm{~g} \mathrm{~kg}^{-1} \mathrm{CHO}$ showed greater retention of CP (REcp, $36.3 \pm 6.9 \%$ ) and energy (REge, $23.9 \pm 5.6 \%$ ) in their carcass than fish fed $300 \mathrm{~g} \mathrm{~kg}^{-1} \mathrm{CHO}$ (REcp, $28.9 \pm 3.9 \%$, REge, $18.5 \pm 3.7 \%)$. The highest blood glucose levels $\left(97.7 \pm 32.7 \mathrm{mg} \mathrm{dL}^{-1}\right)$ were observed in fish fed the $300 \mathrm{CHO} / 400 \mathrm{CP}$ diet, and they had a significantly lower mesenteric fat index
\end{abstract}

Leonardo Susumu Takahashi

takahashi@dracena.unesp.br

1 College of Agricultural and Technological Sciences (FCAT), São Paulo State University (UNESP), Rod. Comte. João Ribeiro de Barros, km 651, Dracena, São Paulo 17900-000, Brazil

2 Aquaculture Center of Unesp (Caunesp), São Paulo State University (UNESP), Via de Ac. Prof. Paulo Donato Castellane, s/n, Jaboticabal, São Paulo 14884-900, Brazil 
$(0.85 \pm 0.26 \%)$ than fish fed with the $170 \mathrm{CHO} / 400 \mathrm{CP}$ diet $(1.25 \pm 0.33 \%)$. Hepatic hexokinase activity increased in fish fed $300 \mathrm{~g} \mathrm{~kg}^{-1} \mathrm{CHO}$, resulting in an activity of $5.0 \mu \mathrm{mol} \mathrm{mg}^{-1}$ of protein, whereas fish fed $170 \mathrm{~g} \mathrm{~kg}^{-1} \mathrm{CHO}$ had an activity of $3.2 \mu \mathrm{mol} \mathrm{mg}^{-1}$ of protein. These results demonstrate that dietary $\mathrm{CHO}$ directly affect the intermediary metabolism of $P$. reticulatum and feeding $300 \mathrm{~g} \mathrm{~kg}^{-1} \mathrm{CHO}$ and $440 \mathrm{~g} \mathrm{~kg}^{-1} \mathrm{CP}$ should be considered excessive as it results in decreased nutrient retention in the carcass and decreased growth performance despite metabolic adjustments.

Keywords Hepatic enzymes · Growth · Dietary starch $\cdot$ Feed formulation

\section{Introduction}

Carnivorous fish do not frequently consume carbohydrates (CHO) due to the composition of their natural diet (Hemre et al. 2002). The digestive and metabolic systems of carnivorous fishes appear to be more adapted to use proteins and lipids as energy sources (Dabrowski and Guderley 2002). However, this generalization may not always hold true as there are striking morphological and physiological differences even within fishes that have similar feeding habits, and these differences can lead to differences in the dietary utilization of CHO (Kamalam et al. 2017).

Adequate levels of non-structural $\mathrm{CHO}$, such as starch, can promote a protein-sparing effect, which ultimately results in an optimal cost/benefit ratio and a reduction in ammonia excretion (Enes et al. 2009; Pérez-Jiménez et al. 2015). Non-protein energy sources in the diet, like CHO, allow proteins to be used for fish growth (Kamalam et al. 2017). Glucose is an important metabolic stimulant for glucose-dependent tissues because available dietary CHOs can reduce gluconeogenic activity and lead to the use of amino acids for building structural proteins instead of in the oxidative pathway (Hemre et al. 2002).

Complex CHO sources, such as starch and dextrins, are more efficiently used than simple sugars in most fish species (Wilson 1994). However, in some carnivorous fishes, such as gilthead seabream (Sparus aurata), dietary glucose is more effective at stimulating hepatic glycolytic activity than dietary starch. This result has been attributed to higher glycaemia and an increase in glucose uptake by the liver (Enes et al. 2010).

The inclusion of high levels of $\mathrm{CHO}$ in diets in an attempt to reduce the protein levels has been attempted for some carnivorous species, such as European sea bass (Dicentrarchus labrax), brook trout (Salvelinus fontinalis), Senegalese sole (Solea senegalensis), and golden pompano (Trachinotus ovatus), with no impairment of productive performance and with a direct relationship to intermediary metabolism (Enes et al. 2006; Amin et al. 2014; Guerreiro et al. 2014; Zhou et al. 2015).

South American catfishes (Pseudoplatystoma sp.) are the most important and widely cultivated group of piscivorous fish in Brazil (Brasil 2012). Their meat is of excellent quality, and it has few spines in the fillets, a clear coloration, and a firm texture (Campos 2010). The surubim cachara (Pseudoplatystoma reticulatum formerly $P$. fasciatum from the Amazon and Paraná rivers) (Buitrago-Suárez and Burr 2007) is preferentially carnivorous and has a gastrointestinal tract that is typical of carnivorous fish. However, this species retains some anatomical peculiarities that indicate adaptations to an omnivorous diet, such as the longitudinal pattern of its gastrointestinal tract and the presence of several anastomoses that slow the advancement of food, providing a longer digestive period and, consequently, better nutrient utilization (Rodrigues et al. 2009). 
P. reticulatum is a commercially important carnivorous species, but there is a lack of knowledge about its physiological mechanisms related to nutritional requirements, especially about $\mathrm{CHO}$ metabolism. The commercial feeds commonly used in P. reticulatum farming contain approximately $420 \mathrm{~g}$ crude protein (CP) kg-1 and $80 \mathrm{~g}^{-1}$ crude lipid kg-1 (Campos 2010), but these levels should be optimized, mainly regarding the non-protein energy content. The objective of the present study was to evaluate the effects of dietary protein and $\mathrm{CHO}$ on the growth performance and physiological responses of juvenile $P$. reticulatum.

\section{Materials and methods}

\section{Experimental diets}

Six experimental diets were formulated to be isoenergetic (18.0 MJ gross energy $(\mathrm{GE}) \mathrm{kg}^{-1}$ ) and isolipidic (70 $\mathrm{g}$ crude lipid (CL) $\mathrm{kg}^{-1}$ ) with three CP levels $\left(360,400\right.$, or $\left.440 \mathrm{~g} \mathrm{~kg}^{-1}\right)$ and two CHO levels ( 170 or $300 \mathrm{~g} \mathrm{~kg}^{-1}$ ), as shown in Table 1 . Fish meal and poultry viscera meal were used as the main protein sources, fish oil as the lipid source, and pre-gelatinized starch as the $\mathrm{CHO}$ source.

The proximate composition of the ingredients and experimental diets were determined according to the methods described by the AOAC (2000). Dry matter (DM) content was determined by drying samples in an oven at $105^{\circ} \mathrm{C}$ for $24 \mathrm{~h}, \mathrm{CP}$ content was determined as the total nitrogen $(\mathrm{N})$ content using the Kjeldahl method, CL content was analyzed by Soxhlet extraction with petroleum ether, and ash content was determined by incinerating the dried samples at $600{ }^{\circ} \mathrm{C}$ for $4 \mathrm{~h}$ in an electric furnace. GE was determined by using an oxygen bomb-calorimeter (C200 Control, Ika, Guangzhou, China). Dietary starch was analyzed according to the methodology described by Beutler (1984) using enzymatic analysis after samples had been pretreated to convert the starch into a soluble form. The ingredients were milled and mixed, and the diets were pelleted with added water $\left(200 \mathrm{~g} \mathrm{~kg}^{-1}\right)$ and dried at $40{ }^{\circ} \mathrm{C}$ for $12 \mathrm{~h}$. The diets were stored in plastic containers and kept at $8{ }^{\circ} \mathrm{C}$ during the experiment.

\section{Fish and experimental conditions}

Juveniles of $P$. reticulatum from the same spawning were acquired from a commercial producer (Piraí fish farm, Terenos, Mato Grosso do Sul, Brazil). Fish were allocated in 130-L polyethylene tanks and maintained for 4 weeks to adapt to the laboratory condition. Tanks were supplied with continuously circulating freshwater and aeration (electric aerator CR3, Ibram Ind. Brasileira de Máquinas Ltda, São Paulo, São Paulo, Brazil), and the temperature was controlled with electric heaters (Guangdong Boyu Group Co., Raoping, Guangdong, China). A constant 12 h light/12 h dark photoperiod was maintained. The fish were fed to apparent satiation twice a day ( $18 \mathrm{~h} 00 \mathrm{~min}$ and $00 \mathrm{~h} 30 \mathrm{~min}$ ) with a commercial feed for carnivorous fish (Pirá 40 4-5 mm: $400 \mathrm{~g} \mathrm{CP} \mathrm{kg}^{-1}, 80 \mathrm{~g} \mathrm{CL}$ $\mathrm{kg}^{-1}$; Guabi Nutrição e Saúde Animal S.A., Campinas, São Paulo, Brazil).

After acclimation, 20 fish were sampled for the initial whole-body composition analysis. The remaining fish were starved $\left(12 \mathrm{~h}\right.$ ), anesthetized (benzocaine, $0.1 \mathrm{~g} \mathrm{~L}^{-1}$ ), and individually weighed. Fish (69.2 $\pm 4.4 \mathrm{~g})$ were distributed among 24 130-L polyethylene tanks (4 tanks/ treatment) at a stocking density of eight fish/tank.

During the experiment, fish were fed with the experimental diets twice a day (18 h $00 \mathrm{~min}$ and $00 \mathrm{~h} 30 \mathrm{~min}$ ) until apparent satiation for 60 days. Each experimental diet was distributed to four replicates (tanks). Apparent satiation was defined as the time when the fish refused to eat the food offered. Food intake was determined by weighing the food containers daily. 
Table 1 Composition of the experimental diets

\begin{tabular}{|c|c|c|c|c|c|c|}
\hline \multirow[t]{2}{*}{7} & \multicolumn{3}{|c|}{$170 \mathrm{CHO}$} & \multicolumn{3}{|c|}{$300 \mathrm{CHO}$} \\
\hline & $360 \mathrm{CP}$ & $400 \mathrm{CP}$ & $440 \mathrm{CP}$ & $360 \mathrm{CP}$ & $400 \mathrm{CP}$ & $440 \mathrm{CP}$ \\
\hline \multicolumn{7}{|l|}{ Ingredients ${ }^{1}, \mathrm{~g} \mathrm{~kg}^{-1}$} \\
\hline Fish meal ${ }^{2}$ & 260 & 260 & 260 & 260 & 260 & 260 \\
\hline Poultry viscera meal ${ }^{3}$ & 243 & 305 & 366 & 243 & 305 & 366 \\
\hline Soy protein concentrate ${ }^{4}$ & 50 & 50 & 50 & 50 & 50 & 50 \\
\hline Pre-gelatinized starch $^{5}$ & 171 & 171 & 171 & 285 & 285 & 285 \\
\hline Fish oil $^{6}$ & 29 & 22 & 14 & 29 & 22 & 14 \\
\hline Vitamins and minerals ${ }^{7}$ & 18 & 18 & 18 & 18 & 18 & 18 \\
\hline Cellulose $^{8}$ & 182 & 127 & 74 & 68 & 13 & 7 \\
\hline Kaolin & 47 & 47 & 47 & 47 & 47 & 0 \\
\hline \multicolumn{7}{|l|}{ Analyzed composition } \\
\hline Dry matter, $\mathrm{g} \mathrm{kg}^{-1}$ & 965 & 964 & 957 & 953 & 947 & 949 \\
\hline Crude protein, $\mathrm{g} \mathrm{kg}^{-1}$ & 374 & 417 & 448 & 375 & 399 & 445 \\
\hline Crude lipid, $\mathrm{g} \mathrm{kg}^{-1}$ & 73 & 76 & 66 & 68 & 63 & 80 \\
\hline Ash, $\mathrm{g} \mathrm{kg}^{-1}$ & 118 & 152 & 155 & 140 & 148 & 113 \\
\hline Carbohydrates (starch), $\mathrm{g} \mathrm{kg}^{-1}$ & 172 & 173 & 190 & 306 & 299 & 303 \\
\hline Gross energy, $\mathrm{MJ} \mathrm{kg}^{-1}$ & 18.23 & 17.92 & 18.01 & 17.90 & 17.94 & 19.03 \\
\hline
\end{tabular}

${ }^{1}$ Enrichment per kilogram of feed: vit $\mathrm{A}$ (3000 IU), vit $\mathrm{D}_{3}$ (3000 IU), vit E (200.0 mg), vit $\mathrm{B}_{1}(6.0 \mathrm{mg})$, vit $\mathrm{B}_{2}$ $(8.0 \mathrm{mg})$, vit $\mathrm{B}_{6}(3.0 \mathrm{mg})$, vit $\mathrm{B}_{12}(20.0 \mathrm{mg})$, vit $\mathrm{C}(350.0 \mathrm{mg})$, vit $\mathrm{K}(6.0 \mathrm{mg})$, folic ac. $(1.0 \mathrm{mg})$, pantothenic ac. (20.0 mg), Biotine (0.1 mg), Niacin (100.0 mg), Choline (150.0 mg), Cu (10.0 mg), Fe (100.0 mg), I (5.0 mg), Mn (70.0 mg), Zn (150.0 mg), B.H.T. (125.0 mg)

${ }^{2}$ Pesquera Pacific Star, Puerto Montt, Chile. CP $651.7 \mathrm{~g} \mathrm{~kg}^{-1}$

${ }^{3}$ Adamantina Alimenta, Adamantina, São Paulo, Brazil. CP $652.1 \mathrm{~g} \mathrm{~kg}^{-1}$

${ }^{4}$ ADM do Brasil Ltda, Paranagua, Paraná, Brazil. CP $634.4 \mathrm{~g} \mathrm{~kg}^{-1}$

${ }^{5}$ Ingredion Incorporated, Mogi Guaçu, São Paulo, Brazil

${ }^{6}$ Cristalina Fish Farm (Mauro Nakata), Fartura, São Paulo, Brazil

${ }^{7}$ Poli-Nutri Alimentos SA., Osasco, São Paulo, Brazil

${ }^{8}$ Rhoster Indústria e Comércio Ltda, Araçoiaba da Serra, São Paulo, Brazil

The organic matter deposited on the bottom of the tanks was removed via siphoning with a rubber hose. The water temperature, dissolved oxygen content (YSI 55 dissolved oxygen, YSI Incorporated, Yellow Springs, Ohio, USA), $\mathrm{pH}$, and total ammonia content (YSI Professional Plus, YSI Incorporated, Yellow Springs, Ohio, USA) were monitored daily. Water quality parameters were as follows: temperature $\left(25.7 \pm 1.9^{\circ} \mathrm{C}\right)$, dissolved oxygen $\left(5.4 \pm 0.9 \mathrm{mg} \mathrm{L}^{-1}\right)$, $\mathrm{pH}(7.6 \pm 0.06)$, and total ammonia $\left(0.06 \pm 0.002 \mathrm{mg} \mathrm{N}-\mathrm{NH}_{4} \mathrm{~L}^{-1}\right)$.

\section{Measurements and analytical methods}

After 60 days of feeding, fish were starved for $12 \mathrm{~h}$, anesthetized (benzocaine, $0.1 \mathrm{~g} \mathrm{~L}^{-1}$ ), and weighed to determine their final weight (FW), weight gain (WG), specific growth rate (SGR), feed consumption index (FCI), apparent feed conversion (AFC), and protein efficiency ratio (PER). Three fish per tank were randomly collected and stored at $-20{ }^{\circ} \mathrm{C}$ for whole-body composition analysis.

WG $(\mathrm{g})$

$\operatorname{SGR}\left(\%\right.$ day $\left.^{-1}\right)$ FCI (\% BW day $\left.{ }^{-1}\right)$ final weight - initial weight;

$100 \times[(\ln$ final weight $-\ln$ initial weight $) /$ experimental period $]$;

$100 \times($ daily consumption/average body weight); 
AFC

PER (\%)

food supplied/weight gain;

The DM, CP, CL, and ash contents of whole fish were analyzed according to the methods described by the AOAC (2000), as cited above. Whole-body GE was determined using an oxygen bomb-calorimeter (C200 Control, Ika, Guangzhou, China). Whole-body composition was determined to evaluate the retention efficiency of crude protein (REcp) and retention efficiency of gross energy (REge).

REcp $(\%) \quad 100 \times[(\mathrm{CP}$ final carcass $\times \mathrm{FW})-(\mathrm{CP}$ initial carcass $\times \mathrm{IW})] / \mathrm{CP}$ consumed; REge $(\%) \quad 100 \times[(\mathrm{GE}$ final carcass $\times \mathrm{FW})-(\mathrm{GE}$ initial carcass $\times \mathrm{IW})] / \mathrm{GE}$ consumed.

Blood samples were taken from the caudal vasculature of another three fish per tank (12 fish/treatment) with heparinized syringes and were centrifuged $\left(827 \mathrm{~g}, 10 \mathrm{~min}, 4{ }^{\circ} \mathrm{C}\right)$ and stored at $-20{ }^{\circ} \mathrm{C}$ to measure blood metabolites. The concentrations of the following metabolites were analyzed: plasma glucose (GOD-Trinder method, Gold Analisa Diagnostica, Belo Horizonte, Brazil), serum triglycerides (Enzimatic-Trinder method, Gold Analisa Diagnostica, Belo Horizonte, Minas Gerais, Belo Horizonte, Brazil), and total serum protein (Biuret method, Reinhold 1953).

Then, fish were euthanized, and a laparotomy was performed to collect and weigh the mesenteric fat in the visceral cavity and the liver. Liver samples were stored at $-80{ }^{\circ} \mathrm{C}$ and used for the measurement of hepatic metabolic enzymes, total lipids (Bligh and Dyer 1959), and glycogen (Perry et al. 1988). The mesenteric fat index (MFI) and hepatosomatic index (HSI) were evaluated.

MFI (\%) $100 \times($ weight of mesenteric fat $/ \mathrm{FW})$;

HSI $(\%) \quad 100 \times($ weight of liver/FW).

Hepatic enzyme activity was evaluated by measuring glucokinase (GK, EC 2.7.1.2) and hexokinase (HK, EC 2.7.1.1), both of which are enzymes from the glycolytic pathway. Glucose6-phosphate dehydrogenase (G6PD, EC 1.1.1.49), from the lipogenic pathway, and aspartate aminotransferase (AST, EC 2.6.1.1), from the amino acid metabolism, were also measured.

Briefly, to measure the activity of key enzymes, liver samples were homogenized (dilution 1:4) in ice-cold buffer (100 mM Tris- $\mathrm{HCl}, 0.1 \mathrm{mM}$ EDTA, and $0.1 \%(v / v)$ Triton X-100 at $\mathrm{pH}$ 7.8). Homogenates were centrifuged at $30,000 \mathrm{~g}$ for $30 \mathrm{~min}$ at $4{ }^{\circ} \mathrm{C}$. $\mathrm{HK}$ and $\mathrm{GK}$ activities were determined as described by Vijayan et al. (1990). The reaction mixture contained $50 \mathrm{mM}$ imidazole-HCl buffer (pH 7.4), $2.5 \mathrm{mM}$ ATP, $5 \mathrm{mM} \mathrm{MgCl}_{2}, 0.4 \mathrm{mM}$ NADP, 2 units $\mathrm{mL}^{-1}$ G6PD, and $1 \mathrm{mM}(\mathrm{HK})$ or $100 \mathrm{mM}$ (HK-IV) glucose.

G6PD activity was measured as described by Morales et al. (1990) using a reaction mixture containing $50 \mathrm{mM}$ imidazole- $\mathrm{HCl}$ buffer (pH 7.4), $5 \mathrm{mM} \mathrm{MgCl}_{2}, 2 \mathrm{mM} \mathrm{NADP}$, and $1 \mathrm{mM}$ glucose-6-phosphate. AST activities were measured using a commercial kit (Gold Analisa Diagnostica, Belo Horizonte, Minas Gerais, Brazil). All enzyme activities were measured in a microplate reader (Multiskan GO Microplate Spectrophotometer, Thermo Fisher Scientific Inc., Madison, WI, USA). The specific activities of the enzymes are expressed in units of tissue protein, with bovine serum albumin as the standard (Cain and Skilleter 1987).

\section{Statistical analyses}

After being tested for normality (Cramer Von Mises) and homoscedasticity (Brown-Forsythe), data were analyzed by two-way ANOVA followed by Tukey's test for the comparison of 
means. Treatment effects were considered significant at $P<0.05$. Results are expressed as the means \pm SD. All analyses were performed using SAS 9.0 (SAS Inst. Inc., Raleigh, NC, USA).

\section{Results}

\section{Growth performance}

The levels of protein influenced $(P<0.05)$ the SGR, FCI, and AFC, and the best results were observed in fish that consumed $440 \mathrm{~g} \mathrm{~kg}^{-1} \mathrm{CP}$ (Table 2). Fish that consumed diets with $170 \mathrm{~g} \mathrm{~kg}^{-1} \mathrm{CHO}$ showed better $(P<0.05) \mathrm{FW}$, WG, SGR, AFC, and PER than those that consumed diets with $300 \mathrm{~g} \mathrm{~kg}^{-1} \mathrm{CHO}$.

\section{Whole-body composition and nutrient retention}

Fish fed $170 \mathrm{~g} \mathrm{~kg}^{-1} \mathrm{CHO}$ showed higher REcp and REge $(P<0.05)$ than those that consumed $300 \mathrm{~g} \mathrm{~kg}^{-1} \mathrm{CHO}$, but CP did not have a significant effect $(P>0.05)$ (Table 3$)$. The levels of dietary $\mathrm{CP}$ and $\mathrm{CHO}$ did not influence $(P>0.05)$ the whole-body composition (Table 3$)$.

\section{Blood and tissue metabolism}

No differences were observed $(P>0.05)$ in the serum triglycerides and total protein concentrations (Table 4). An interaction was observed between the levels of dietary CP and CHO in the plasma glucose. Fish that consumed the $300 \mathrm{CHO} / 400 \mathrm{CP}$ diet showed the highest blood glucose level $(P<0.05)$.

The HSI and hepatic glycogen and lipid contents were not influenced by the treatments $(P>0.05)$ (Table 4). Fish that were fed $360 \mathrm{~g} \mathrm{~kg}^{-1} \mathrm{CP}$ displayed higher hepatic lipid levels than fish fed higher $\mathrm{CP}$ content in both $\mathrm{CHO}$ levels. An interaction was observed between the levels of CP and CHOs on the MFI (Table 4), which was lower in fish fed the 300CHO/400CP diet than in the other groups $(P<0.05)$.

\section{Hepatic metabolic enzymes}

No interactions were observed between the dietary levels $\mathrm{CP}$ and $\mathrm{CHO}$ for the hepatic activities of GK, HK, and G6PD $(P>0.05)$ (Table 5). The hepatic activity of HK increased $(P<0.05)$ in fish that consumed diets with $300 \mathrm{~g} \mathrm{~kg}^{-1} \mathrm{CHO}$, and the activity of G6PD increased $(P<0.05)$ in fish that were fed diets with $440 \mathrm{~g} \mathrm{~kg}^{-1} \mathrm{CP}$. A significant interaction effect was found for hepatic AST activity (Table 5), which was increased in fish fed with the $170 \mathrm{CHO} / 440 \mathrm{CP}$ and $300 \mathrm{CHO} / 400 \mathrm{CP}$ diets.

\section{Discussion}

Dietary $\mathrm{CHO}$ directly affect the intermediary metabolism of $P$. reticulatum, but high levels result in worse growth performance. The dietary $\mathrm{CHO}$ requirements of fish have not been determined, but previous studies have shown that dietary $\mathrm{CHO}$ can interfere with growth performance when administered at very high levels, as observed in grass carp 


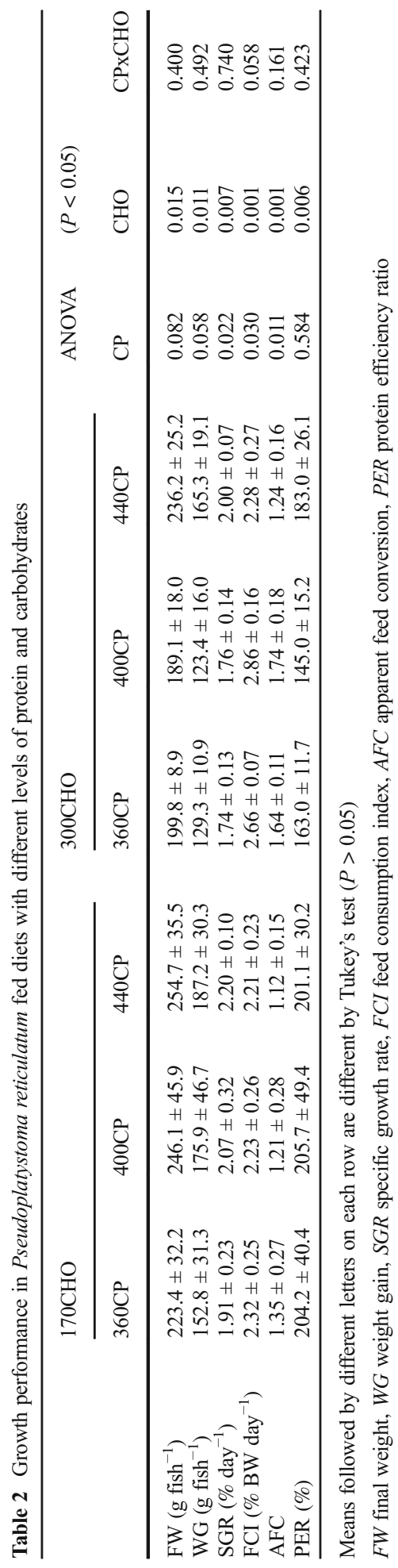




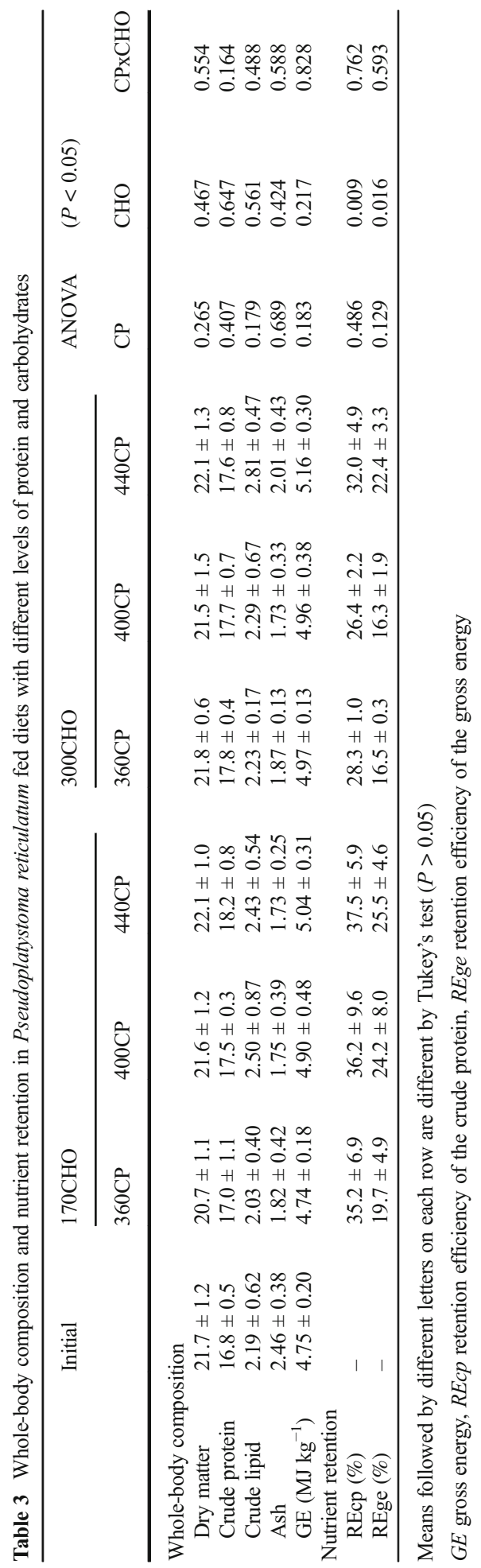




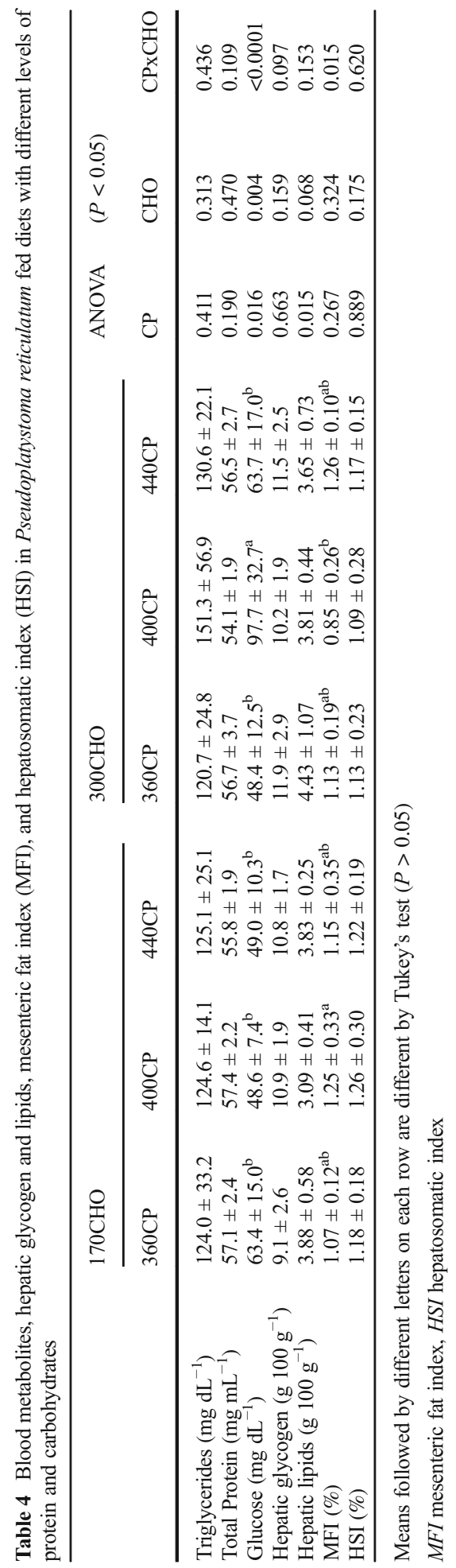


(Ctenopharyngodon idella) fed diets with more than $400 \mathrm{~g} \mathrm{~kg}^{-1}$ wheat starch (Tian et al. 2012) and in golden pompano receiving more than $224 \mathrm{~g} \mathrm{~kg}^{-1} \mathrm{CHO}$ (Zhou et al. 2015). However, diets with little or no CHO can also result in this effect (Dabrowski and Guderley 2002).

In this study, the high amount of $\mathrm{CHO}$ in the diet directly influenced the growth of $P$. reticulatum, and fish that consumed diets with $300 \mathrm{~g} \mathrm{~kg}^{-1} \mathrm{CHO}$ showed lower growth performance than fish that consumed diets with $170 \mathrm{~g} \mathrm{~kg}^{-1}$ CHO. In juvenile Pseudoplatystoma corruscans, another South American catfish, diets with up to $250 \mathrm{~g} \mathrm{~kg}^{-1}$ $\mathrm{CHO}$ and $300 \mathrm{~g} \mathrm{~kg}^{-1} \mathrm{CP}$, given for 28 days, did not influence growth performance (Lundstedt et al. 2004). In other study, $P$. corruscans juvenile fed diets with up to $290 \mathrm{~g} \mathrm{~kg}^{-1}$ of nonstructural CHO showed no impairment in growth and feed conversion, which can be attributed to the utilization of $\mathrm{CHO}$ as an energy source, which spared proteins for use in growth, leading to weight gain (Takahashi and Cyrino 2006).

A better nutrient balance is essential, since lower dietary CHO level $\left(170 \mathrm{~g} \mathrm{~g}^{-1}\right)$ with an appropriate level of protein $\left(440 \mathrm{~g} \mathrm{~kg}^{-1}\right)$ and fat $\left(66 \mathrm{~g} \mathrm{~kg}^{-1}\right)$ resulted in a more efficient retention of $\mathrm{CP}$ and better retention of $\mathrm{GE}$, as demonstrated in previous studies with other carnivorous fish, suggesting that these diets provided $\mathrm{CHO}$ for use as an energy source and allowed proteins to be spared for growth (Shiau and Lin 2001; Enes et al. 2006; Amin et al. 2014; Zhou et al. 2015).

The fish fed the highest protein level, the most expensive component in the diet, showed an increased on hepatic AST activity, suggesting that amino acids were metabolized and contributed to providing energy; thus, glucose was derived from amino acids (Enes et al. 2009). In addition, it was observed that the $300 \mathrm{CHO} / 400 \mathrm{CP}$ diet also stimulated the AST activity, a key enzyme for the metabolism of amino acids for energy production, triggering this metabolic pathway at the cost of using amino acids for animal growth. It means that amino acids acquired from a high protein diet were used, rather than CHO, for energy production (Enes et al. 2006; Kumar et al. 2009). In brown trout fed with a low protein and high CHO diet (Salmo trutta), there was not observed negative effect in protein synthesis, although protein accretion decreased, suggesting an increase in protein degradation. However, the principal components of the main tissues (liver, muscle, and gut) were not affected (Viaplana-Marín et al. 2006).

In European sea bass (Dicentrarchus labrax) fed diets with $200 \mathrm{~g} \mathrm{~kg}^{-1} \mathrm{CHO}$, metabolic activities suggested that the $\mathrm{CHO}$ significantly improved protein use due to the increased activity of glycolytic enzymes, such as GK and HK, along with decreased gluconeogenesis (Enes et al. 2006). In addition, in golden pompano fed diets with up to $168 \mathrm{~g} \mathrm{~kg}^{-1} \mathrm{CHO}$, increased glycolysis and decreased amino acid catabolism, however, the higher levels worsened the growth performance (Zhou et al. 2015). High dietary CHO or lipid contents have been shown to significantly depress growth and feed utilization and influence the glycolytic pathway in another carnivorous fish, the yellow croaker (Larmichthys crocea) (Zhou et al. 2016). Accordingly, in juvenile $P$. reticulatum, the high levels of dietary $\mathrm{CHO}$, although promoted greater hepatic HK activity, resulted in higher plasma glucose levels with higher dietary CP.

One of the major functions of the liver is to extract glucose from the bloodstream and store it as glycogen and, if necessary, to mobilize it through glycogen hydrolysis (Higuera and Cardenas 1984). A previous study on the effects of glucose, dextrin, and starch on the growth and body composition of starry flounder (Platichthys stellatus) showed an increase in the HSI, with elevated levels of starch, which was directly related to the deposition of hepatic glycogen (Lee and Lee 2004).

The use of CHO by various species depends on the animal's ability to oxidize glucose and store the excess as glycogen or lipids (Xiao et al. 2014). In this study, hepatic lipids showed no significant differences between fish fed diets with different $\mathrm{CHO}$ levels. However, fish that 


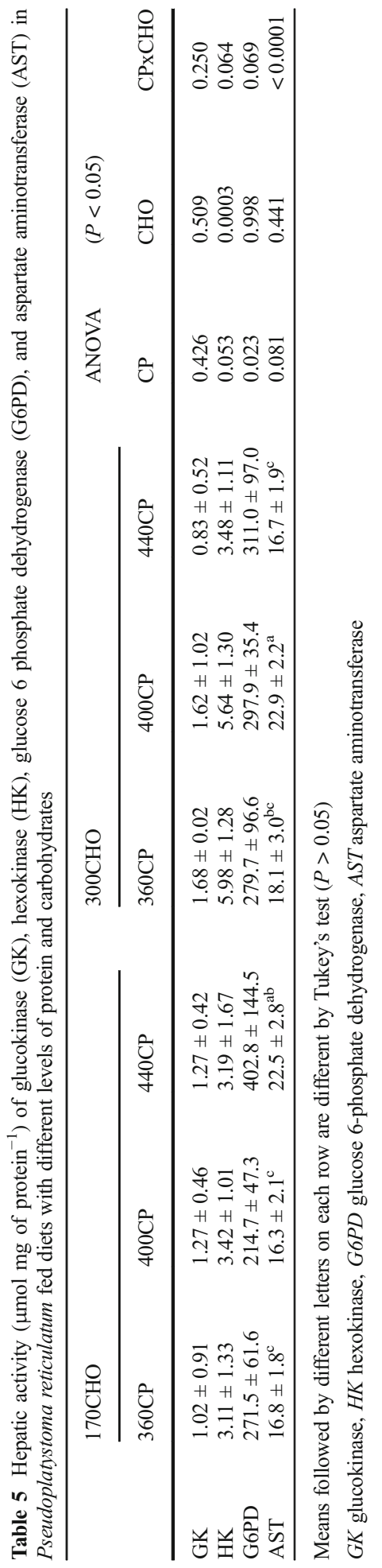


consumed diets with $360 \mathrm{~g} \mathrm{~kg}^{-1} \mathrm{CP}$ showed higher hepatic lipid levels. In mammals, a protein deficiency can induce non-alcoholic hepatic steatosis (Castro et al. 2009). Currently, there are several other known routes of induction, such as deficiencies of choline and methionine (Kirsch et al. 2003), a fat-rich diet (Gauthier et al. 2003; Lieber et al. 2004), and a simple CHO-rich diet (Zivkovic et al. 2007).

Normally, the growth of fish is not further improved when dietary protein exceeds the optimal requirements. For example, tilapia fed an extruded diet containing $310 \mathrm{~g} \mathrm{~kg}^{-1} \mathrm{CP}$ showed growth similar to that of fish fed an extruded diet containing $310 \mathrm{~g} \mathrm{~kg}^{-1} \mathrm{CP}$ (Ma et al. 2015). Despite the carnivorous feeding habits of $P$. reticulatum, a CP concentration of $440 \mathrm{~g} \mathrm{~kg}^{-1}$ appears to be excessive because it did not improve growth performance relative to fish fed diets with $360 \mathrm{~g} \mathrm{~kg}^{-1} \mathrm{CP}$, and it increased levels of hepatic lipids through the activation of lipogenesis.

Lipogenesis was detected by measuring hepatic G6PD activity (Pérez-Jiménez et al. 2007). Hepatic G6PD activity increased only in fish fed diets with $440 \mathrm{~g} \mathrm{~kg}^{-1} \mathrm{CP}$, the highest protein level tested, even though an increase in fat content was not found in the carcasses of these fish. In the other hand, an interaction between $\mathrm{CP}$ and $\mathrm{CHO}$ levels was observed for the MFI. The $300 \mathrm{CHO} / 400 \mathrm{CP}$ diet resulted in the least amount of mesenteric fat, which shows that the $\mathrm{CHO}$ were used efficiently as an energy source, without impairing growth performance, resulting in the efficient use of protein for growth.

There was an imbalance in glucose homeostasis according to the data, and this imbalance resulted in a malfunction in the absorption of hepatic glucose (glycolysis) and glucose production (gluconeogenesis) (Panserat et al. 2001; Enes et al. 2009). Thus, further investigation involving metabolic enzymes must be carried out to elucidate these mechanisms.

\section{Conclusion}

Using $300 \mathrm{~g} \mathrm{~kg}^{-1} \mathrm{CHO}$ in the diet of $P$. reticulatum should be considered excessive because it affects the glycolytic pathway and decreases productive indices. Despite the carnivorous feeding habits of $P$. reticulatum, $440 \mathrm{~g} \mathrm{~kg}^{-1} \mathrm{CP}$ was excessive, suggested by the activation of the lipogenic pathway. These findings indicate that the balance of nutrients leads to their differential use in the regulation of fish metabolism.

Acknowledgements We thank the Research Foundation of São Paulo (FAPESP) for the grants, Ingredion Incorporated for providing the pre-gelatinized starch, ADM Brazil for the supply of soy protein concentrate, and Poli-Nutri Food for the ingredients in the diets.

\section{References}

AOAC (2000) Official methods of analysis of AOAC international, 17th edn. Association of Official Analytical Chemists, Gaithersburg

Amin MN, Barnes RK, Adams LR (2014) Effects of different protein and carbohydrate levels on growth performance and feed utilization of brook trout, Salvelinus fontinalis (Mitchill, 1814), at two temperatures. J Appl Ichthyol 30:340-349

Beutler HO (1984) Starch. In: Bergmeyer HU (ed) Methods of enzymatic analysis. Verlag, Chemie Weinheim, Basel, pp 2-10 
Bligh EG, Dyer WJ (1959) Rapid method of total lipid extraction and purification. Can J Biochem Physiol 37 : 911-917

Brasil (2012) Boletim estatístico da pesca e aquicultura: Brasil 2010. Ministério da Pesca e Aquicultura, Brasília, Brazil

Buitrago-Suárez UA, Burr BM (2007) Taxonomy of the catfish genus Pseudoplatystoma Bleeker (Siluriformes: Pimelodidae) with recognition of eight species. Zootaxa 1512:1-38

Cain K, Skilleter DN (1987) Preparation and use of mitochondria in toxicological research. In: Snell K, Mullock B (eds) Biochemical toxicology. IRL Press, Oxford, pp 217-254

Campos JL (2010) O cultivo do pintado (Pseudoplatystoma corruscans, Spix; Agassiz, 1829), e outras espécies do gênero Pseudoplatystoma e seus híbridos. In: Baldisserotto B, Gomes LC (eds) Espécies nativas para piscicultura no Brasil. UFSM, Santa Maria, pp 335-361

Castro GSF, Mialich MS, Anjos EM et al (2009) Caracterização da esteatose hepática não alcoólica induzida por dieta hipoprotéica em ratos. Medicina 42:48-53

Dabrowski K, Guderley H (2002) Intermediary metabolism. In: Halver JE, Hardy RW (eds) Fish nutrition. Academic Press, New York, pp 309-365

Enes P, Panserat S, Kaushik S et al (2006) Effect of normal and waxy maize starch on growth, food utilization and hepatic glucose metabolism in European sea bass (Dicentrarchus labrax) juveniles. Comp Biochem Phys A 143:86-96

Enes P, Panserat S, Kaushik S et al (2009) Nutritional regulation of hepatic glucose metabolism. Fish Physiol Biochem 35:519-539

Enes P, Peres H, Couto A et al (2010) Growth performance and metabolic utilization of diets including starch, dextrin, maltose or glucose as carbohydrate source by gilthead sea bream (Sparus aurata) juveniles. Fish Physiol Biochem 36:903-910

Gauthier MS, Couturier K, Latour JG et al (2003) Concurrent exercise prevents high-fat-diet-induced macrovesicular hepatic steatosis. J Appl Physiol 94:2127-2134

Guerreiro I, Peres H, Castro C et al (2014) Water temperature does not affect protein sparing by dietary carbohydrate in Senegalese sole (Solea senegalensis) juveniles. Aquac Res 45:289-298

Hemre GI, Mommsen TP, Krogdahl A (2002) Carbohydrates in fish nutrition: effects on growth, glucose metabolism and hepatic enzymes. Aquac Nutr 8:175-194

Higuera M, Cardenas P (1984) Influence of dietary composition on gluconeogenesis from L-(U-14C) glutamate in rainbow trout (Salmo gairdneri). Comp Biochem Physiol 81:391-395

Kamalam BS, Medale F, Panserat S (2017) Utilization of dietary carbohydrates in farmed fishes: new insights on influencing factors, biological limitations and future strategies. Aquaculture 467:3-27

Kirsch R, Clarkson V, Shephard EG et al (2003) Rodent nutritional model of non-alcoholic steatohepatitis: species, strain and sex difference studies. J Gastroenterol Hepatol 18:1272-1282

Kumar S, Sahu NP, Pal AK et al (2009) Modulation of key metabolic enzyme of Labeo rohita (Hamilton) juvenile: effect of dietary starch type, protein level and exogenous alpha-amylase in the diet. Fish Physiol Biochem 35:301-315

Lee S, Lee J (2004) Effect of dietary glucose, dextrin and starch on growth and body composition of juvenile starry flounder Platichthys stellatus. Fisheries Sci 70:53-58

Lieber CS, Leo MA, Mak KM et al (2004) Model of nonalcoholic steatohepatitis. Am J Clin Nutr 79:502-509

Lundstedt LM, Melo JFB, Moraes G (2004) Digestive enzymes and metabolic profile of Pseudoplatystoma corruscans (Teleostei: Siluriformes) in response to diet composition. Comp Biochem Phys B 137:331-339

Ma F, Li X, Li B et al (2015) Effects of extruded and pelleted diets with differing protein levels on growth and nutrient retention of tilapia, Oreochromis niloticus x O. aureus. Aquac Int 23:1341-1356

Morales AE, Garcia L, Higuera M (1990) Influence of handling and/or anesthesia on stress response in rainbowtrout — effects on liver primary metabolism. Comp Biochem Phys A 95:87-93

Panserat S, Capilla E, Gutierrez J et al (2001) Glucokinase is highly induced and glucose-6-phosphatase poorly repressed in liver of rainbow trout (Oncorhynchus mykiss) by a single meal with glucose. Comp Biochem Physiol 128:275-283

Pérez-Jiménez A, Guedes MJ, Morales AE et al (2007) Metabolic responses to short starvation and refeeding in Dicentrarchus labrax - effect of dietary composition. Aquaculture 265:325-335

Pérez-Jiménez A, Abellán E, Arizcun M et al (2015) Nutritional and metabolic responses in common dentex (Dentex dentex) fed on different types and levels of carbohydrates. Comp Biochem Phys A 184:56-64

Perry SF, Walsh PJ, Mommsen TP et al (1988) Metabolic consequences of hypercapnia in the rainbow trout Salmo gairdneri: $\beta$-adrenergic effects. Gen Comp Endocrinol 69:439-447

Reinhold JG (1953) Manual determination of serum total protein, albumin and globulin fraction by biuret method. In: Reiner M (ed) Standard method of clinical chemistry. Academic Press, Ney work, p 88

Rodrigues APO, Pauletti P, Kindlein L et al (2009) Intestinal morphology and histology of the striped catfish Pseudoplatystoma fasciatum (Linnaeus, 1766) fed dry diets. Aquac Nutr 15:559-563 
Shiau SY, Lin YH (2001) Carbohydrate utilization and its protein-sparing effect in diets for grouper (Epinephelus malabaricus). Anim Sci 73:299-304

Takahashi LS, Cyrino JEP (2006) Dietary carbohydrate level on growth performance of speckled catfish, Pseudoplatystoma coruscans. J Aquac Trop 21:13-19

Tian LX, Liu YJ, Yang HJ et al (2012) Effects of different dietary wheat starch levels on growth, feed efficiency and digestibility in grass carp (Ctenopharyngodon idella). Aquac Int 20:283-293

Viaplana-Marín I, Fernández-Borrás J, Blasco J (2006) Effects of the protein/carbohydrate ratio of extruded diets on protein synthesis, protein growth and body composition in juvenile brown trout (Salmo trutta). Aquac Int $14: 337-353$

Vijayan MM, Ballantine JS, Leatherland JF (1990) High stocking density alters the energy metabolism of brook charr, Salvelinus fontinalis. Aquaculture 88:371-381

Wilson RP (1994) Utilization of dietary carbohydrate by fish. Aquaculture 124:67-80

Xiao X, Han D, Zhu X et al (2014) Effect of dietary cornstarch levels on growth performance, enzyme activity and hepatopancreas histology of juvenile red swamp crayfish, Procambarus clarkia (Girard). Aquaculture 426:112-119

Zivkovic AM, German JB, Sanyal AJ (2007) Comparative review of diets for the metabolic syndrome: implications for nonalcoholic fatty liver disease. Am J Clin Nutr 86:285-300

Zhou C, Ge X, Niu J et al (2015) Effect of dietary carbohydrate levels on growth performance, body composition, intestinal and hepatic enzyme activities, and growth hormone gene expression of juvenile golden pompano, Trachinotus ovatus. Aquaculture 437:390-397

Zhou P, Wang M, Xie F et al (2016) Effects of dietary carbohydrate to lipid ratios on growth performance, digestive enzyme and hepatic carbohydrate metabolic enzyme activities of large yellow croaker (Larmichthys crocea). Aquaculture 452:45-51 